\title{
CORRESPONDENCE
}

The NHS is dead: long live the NHS

Sir Alec Merrison, DL, FRS............102

Molar dosage of calcium chloride solutions

D A Chamberlain, FRCP, and others.....102

SI: two years on

Eva Lester, MRCPATH.............. 102

Propranolol absorption in Crohn's

disease and coeliac disease

R L Parsons, MRCP, and others . . . . . . 103

Saving money by self-help

D H Ryde, MRCGP; R Law, MRCGP; S L H

Smith, MRCGP...................

Vitamin $D$ status in different subgroups of British Asians

C $\mathrm{T}$ Dollery, FRCP, and others; $M R$

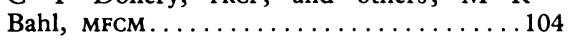

Asthma: Spinhaler usage warning

D C Quantock, MD . . . . . . . . . . . . 104

Metronidazole and anaerobic sepsis Susannah J Eykyn, MRCPATH, and I Phillips, MD; J H B Scarpello, MRCP............ 104

Oestrogens for menopausal flushing

$S$ Campbell, MrCoG, and M I Whitehead,

мB....................... 104
Clonidine and facial flushing in rosacea

W J Cunliffe, MD, and others...........105

D-Penicillamine and fatal obliterative bronchiolitis

W H Lyle, MD . . . . . . . . . . . . . . . . . . 105

Prostatic cancer

L A Price, MRCP, and Bridget T Hill, PHD. . 105

Use of cardiac pacemakers in Britain

H Campbell, FFCM; E T Mathews, FFARCs;

G E Sowton, FRCP............ 106

Quis whatsit?

J S Bradshaw, MB.............. 106

Prescribe British

R B Arnold, PHD . . . . . . . . . . . . . . 107

Chiropody services

G C Jenkins, FCIS

Effect of oral contraceptives on plasma

testosterone concentration

Margaret C K Browning, BSC, and J A R

Anderson, MRCP.................107

Contraceptive dynamism

J A McGarry, FRCOG............. 107

Spontaneous pneumothorax

T Semple, FRCP.............. 107
Retinal vein occlusion

S P B Percival, frCs................ 108

Timing of cervical smears

R Simmons, MRCOG..............108

Integrated approach to asthma

B D Lask, MRCPSYCH . . . . . . . . . . . 108

Management of appendicitis

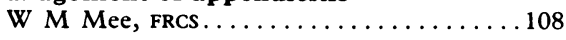

Hip fractures up to date?

G K Morris, MD, and J R A Mitchell, FRCP . 108

Russian roulette

B Haigh, MD . . . . . . . . . . . . . . . 109

Overseas doctors, the BMJ, and the EEC

S S Chatterjee, FRCP............... 109

Recruitment to community medicine

K F R Schiller, DM............... 109

Points from letters Sydney's radio doctor service ( $R$ Tym); Unilateral thoracic hyperhidrosis in bronchial carcinoma (J C Walsh and others); Depression on holiday (M V Silbert); Insulin U40, U80, or U100? (G A Matthews); Competence to practise (J F

Gordon); Chemotherapy for osteosarcoma

(K W Beetham)..................109
Correspondents are urged to write briefly so that readers may be offered as wide a selection of letters as possible. So many are being received that the omission of some is inevitable. Letters should be signed personally by all their authors.

\section{The NHS is dead: long live the NHS}

SIR,-My attention has been drawn to an "open letter" to me in your issue of 4 December ( $p$ 1376) in which Dr Terry Davies declares that in the Earl Grey lecture I gave in Newcastle earlier this year my "message was to beware of the malicious influence of the Civil Service on, not only Ministers of the Crown, but also on nominated advisory bodies, of which you have had considerable experience."

That is, I am afraid, a complete travesty of what I said. I can best illustrate this by quoting merely one paragraph from my lecture, which occurs after a lengthy account I had given of the decision of the Secretary of State for the Environment, in which I had been very much concerned, to impose traffic restrictions on steel box girder bridges on 16 June 1971 . The paragraph runs:

"Then there were his [the Secretary of State's] officials who again had acted correctly and honourably throughout and, with one exception, had acted with good judgment. That exception was of course on the question of whether, in the rather crude knowledge we had, further measures were needed to protect the public safety. It was a matter of judgment and I believe they got it wrong.'

How that can be translated into "malicious influence" I cannot for the life of me imagine. We all of us make mistakes-even Dr Davies, I am afraid, since his table of mortality of myocardial infarction patients in various hospitals is wholly without meaning until one has the numbers (not percentages) of patients treated so that one can at least judge the statistical reliability of his table. Even with that knowledge the cases would have to be subjected to a good deal of clinical analysis before one could draw the conclusions which Dr Davies is after.

All this is rather a pity since I have found this series of open letters which you have been running most helpful and illuminatingas I am sure my fellow Commissioners have, too.

\section{The University,}

Alec Merrison

Bristol

Molar dosage of calcium chloride solutions

SIR,-Mrs S M Roden and Mr G A Mander (20 November, p 1255) illustrate how confusing calcium chloride preparations are for clinicians and pharmacists but overlook the point of our letter (30 October, p 1068). There are now preparations in different strengths and different degrees of hydration; moreover, different manufacturers use different conventions on their labels. They quote the Evans label, while our objections are to that of McCarthy Laboratories, on one of which is printed only: " $2.5 \mathrm{mmol}$ of calcium ions in $5 \mathrm{ml}$." There is no mention of the metric or percentage equivalent and the manufacturers assume that the prescriber has used the SI derived unit on the prescription sheet or drug record. The DHSS circular on the introduction of SI units into the NHS (HSC (IS) 140) gives no authority for this, stating that doses are to be in metric (SI) units (appendix I, p 7); the use of molar (SI) units clearly contravenes this instruction. When we asked who initiated the change we were informed that it was instigated by several area pharmacists. In Brighton as elsewhere we have used SI units for 20 years; our objections, as clinicians, are primarily with the derived units and now with the unauthorised molar form for prescribing, dispensing, and dosage. This is the result of absurd and uncontrolled adumbrations in the adoption of a derived unit of the Système International.

We suggest that the concentration of calcium chloride solutions should be expressed in weight/volume terms in respect of the anhydrous compound. This would have the virtues of simplicity, uniformity, and safety. It would also conform with the current SI instructions. Unfortunately we practise in days in which the simple and rational seem to be unacceptable.

D A Chamberlain A N G Clark JOANNA SHELDON

Brighton Health District,

Brighton, Sussex

\section{SI: two years on}

SIR,-In spite of all the kicking and screaming a year or two ago SI units have been introduced into over $90 \%$ of chemical pathology laboratories in the United Kingdom and the topic is, if not a dead duck, certainly a moribund one here. Before we bury it, though, we should remember that the "I" in SI stands for 
Use of SI units by laboratories participating in an international quality control scheme, November, 1976

\begin{tabular}{|c|c|c|c|}
\hline & $\begin{array}{c}\text { No of } \\
\text { participants }\end{array}$ & $\underset{\text { units }}{\text { SI }}$ & $\begin{array}{c}\text { Traditional } \\
\text { units }\end{array}$ \\
\hline $\begin{array}{l}\text { France } \\
\text { Holland } \\
\text { Belgium } \\
\text { Eire } \\
\text { Sweden } \\
\text { Norway } \\
\text { Italy } \\
\text { Poland } \\
\text { Switzerland } \\
\text { Germany } \\
\text { Greece } \\
\text { Finland } \\
\text { Iceland }\end{array}$ & $\begin{array}{l}\text { Europe } \\
80 \\
52 \\
33 \\
19 \\
13 \\
5 \\
5 \\
4 \\
3 \\
3 \\
2 \\
1 \\
1\end{array}$ & $\begin{array}{r}0 \\
49 \\
0 \\
5 \\
12 \\
0 \\
0 \\
1 \\
0 \\
0 \\
0 \\
1 \\
0\end{array}$ & $\begin{array}{r}80 \\
3 \\
33 \\
14 \\
1 \\
5 \\
5 \\
3 \\
3 \\
3 \\
2 \\
0 \\
1\end{array}$ \\
\hline Total & 221 & 68 & 153 \\
\hline
\end{tabular}

\begin{tabular}{l|c|c|c}
$\begin{array}{l}\text { Canada } \\
\text { USA }\end{array}$ & $\begin{array}{c}\text { North America } \\
115\end{array}$ & 0 & 115 \\
\hline Total & 56 & 1 & 55 \\
\hline & 171 & 1 & 170 \\
\hline Australasia & &
\end{tabular}

\begin{tabular}{c|c|c|c} 
Australia & $\begin{array}{c}\text { Australasia } \\
174\end{array}$ & 106 & 68 \\
New Zealand & 46 & 60 & 6 \\
\hline Total & 220 & 146 & 74 \\
\hline
\end{tabular}

\begin{tabular}{l|c|r|r}
\hline & Africa & & \\
\hline South Africa & 32 & 10 & 22 \\
Nigeria & 5 & 1 & 4 \\
Zambia & 4 & 1 & 3 \\
Uganda & 1 & 0 & 1 \\
\hline Total & 42 & 12 & 30
\end{tabular}

\begin{tabular}{l|c|c|c}
\multicolumn{1}{c|}{ Total } & 42 & 12 & 30 \\
\hline & .4sia & & \\
Japan & 2 & 0 & 2 \\
Hong Kong & 1 & 1 & 0 \\
India & 1 & 0 & 1 \\
Jordan & 1 & 0 & 1 \\
Singapore & 1 & 0 & 1 \\
Syria & 1 & 0 & 1 \\
\hline \multicolumn{1}{c|}{ Total } & 7 & 1 & 6 \\
\hline Overall total & 661 & 228 & 433
\end{tabular}

"international" and that was what it was all about.

There are 661 laboratories outside the United Kingdom which participate in the Wellcome Group International Quality Control Programme. The accompanying table shows how many of them had changed their reporting units by November 1976. The only uniformity, if one excludes the single participating laboratories in Finland and Hong Kong, is found in those countries where not one laboratory has changed, which include Canada, France, Belgium, Norway, Italy, and, with the exception of one rogue laboratory, the USA. Perhaps all members of expert panels on international standardisation should go home now.

Eva LESTER

North Middlesex Hospital, London N18

\section{Propranolol absorption in Crohn's disease} and coeliac disease

SIR,-Since we have studied the absorption of several drugs with a variety of physicochemical properties in different types of malabsorption syndrome for the past five years $^{1-6}$ we were glad to see that $\operatorname{Dr} R E$ Schneider and his colleagues (2 October, $\mathrm{p}$ 794) have found a similar increase in the mean plasma propranolol concentration in coeliac and Crohn's diseases. We have also found gross changes in the shape of the plasma concentration/time curve after oral administration of several other drugs in Crohn's disease. ${ }^{7-9}$
Dr Schneider and his colleagues found that the increased mean plasma propranolol concentration in their coeliac patients was not statistically significant. However, they studied only eight coeliac patients, all of whom were in remission. Thirteen coeliac patients participated in our study of propranolol absorption in coeliac disease. ${ }^{10}$ We then compared the results from six patients who had taken a gluten-free diet for less than 12 months with those from seven who had taken the diet for more than 12 months. The increased mean plasma propranolol concentration and area under the curve were most marked in the first group. These abnormalities were less apparent (and statistically not significant) in those who had taken a gluten-free diet for more than 12 months. ${ }^{11}$ This explains the apparent discrepancy between the findings of $\mathrm{Dr}$ Schneider and his colleagues and ours.

We were also interested to learn from the letter from Dr B T Cooper and others (6 November, p 1135) that abnormalities have been found in the acid microclimate in untreated coeliac disease and Crohn's disease. On the basis of their suggestion it might be expected that the absorption of drugs with low pKas such as folic acid (pKa 3.5), ${ }^{12}$ aspirin ( $\mathrm{pKa} 3.5)$, and indomethacin ( $\mathrm{pKa}$ 4.6 ) would be impaired in coeliac disease. We have measured the plasma concentration/time curve of salicylate and indomethacin and have found that this does not occur. After soluble aspirin the values in the coeliacs for the peak plasma salicylate concentration and the area under the curve were normal. ${ }^{13}$ The timing of the peak salicylate concentration, however, was significantly earlier in the coeliacs. Computer analysis of the raw data suggested that this was due to faster absorption. After oral indomethacin the shape of the plasma concentration/time curve and the area under the curve were the same in both groups.

These findings confirm that the ora bioavailability of salicylate and indomethacin in coeliac disease is normal. The earlier time of the peak plasma salicylate concentration may be due to faster gastric emptying, which is known to occur in coeliac disease. ${ }^{14}$ Thus the changes in the acid microclimate do not entirely account for the abnormalities of drug absorption that occur in coeliac disease.

R L PARSONS J R TROUNCE

Department of Clinical Pharmacology,

Guy's Hospital Medical School,
London SE1

Department of Clinical Pharmacology, St Bartholomew's Hospital,

London EC1

C M KaY

Parsons, $\mathrm{R} \mathrm{L}$, et al, in Progress in Chemotherapy, ed G K Daikos, vol 1, p 499. Athens, Hellenic

2 Parsons, R L, et al, ibid., p 507.

s Parsons, R L, et al, ibid., p 534 . Parsons, R L, and Kaye, C M, British Clinical Pharmacology, $1974,1,348 \mathrm{P}$.
Parsons, R L, et al, fournal of Antimicrobial Chemo

therapy, 1975, 1, 39. Parsons, R L, et al, in Chemotherapy, Vol 4, ed
J D Williams and A M Geddes, p 191. New York $J \mathrm{D}$ Williams and A M Geddes, p 191. New and London, Plenum Publishing Corp, 1976. microbial Chemotherapy. 1975, 1, suppl, p 59. microbial Chemotherapy. 1975, 1, suppl, p 59 . Williams and A M Geddes, p 219. New York and London, Plenum Publishing Corp, 1976.
L Parsons, R L, Hospital Update, 1976, 2, 221.

Parsons, R L, et al, Gut, 1976, 17, 19.

Parsons, R L, Clinical Pharmacokinetics. In press. Blair, J A, and Matty, A, Clinics in Gastroenterology,

1974, 3, 183 . et al, European fournal of Clinical
Parsons, R L, et Pharmacology. In press.

Moberg, S, and Carlberger, G, Scand
of Gastroenterology, 1974, 9, 17.

\section{Saving money by self-help}

SIR,-In your leading article on this subject (11 December, $\mathrm{p}$ 1408) it is stated that doctors give prescriptions for self-limiting conditions because it is quicker and easier to prescribe than to explain that no treatment is necessary. You go on to comment that "it may take longer to explain the nature of his illness and its management to a patient, but one session of explanation may prevent a whole lifetime of visits for self-limiting disease." How true this is!

For 20 years I have practised thus. As an assistant I was instructed by two principals to issue a prescription at every consultation. In my own practice in 1959 my costs were $80 \%$ of average and yearly that figure was reduced to $20^{\circ}{ }_{0}$ as I understood more the nature of consultations and got to know patients. Yet several letters and articles sent to the Department of Health on this topic drew no response.

Only one person can hold the reins of consultation. Treatment implies a desire to cure and confirms that something needs curing. Educating the patient (doctor-from docere, to teach) clarifies the situation. It is not trivia that bring a patient to a doctor but a change in the patient's attitude from tolerance to anxiety in relation to those trivia that creates the consultation, and it behoves the doctor to understand and interpret this.

Thus I find that prescribing frequency and work load diminish in parallel and that educating and prescribing have an inverse relationship. For 20 years neither my patients nor the DHSS have suffered by this policy.

DAvid RYDE

London SE20

SIR,-Your leading article (11 December, p 1408) implies that more thrifty prescribing habits by general practitioners and more health education of the patient at the time of a consultation may spring from a common root -a desire to treat the whole person and not merely his self-limiting disease or minor symptoms. This, you suggest, could flower in a more self-reliant patient and a considerable saving on money. I agree.

I fear that the continual rise in prescribing costs may lead to curtailment of our liberty to prescribe and that the profession should look to ways of encouraging economy. I propose that any practitioner whose prescribing costs per head fall below $80 \%$ of the area average for four consecutive years should have the chance to claim the percentage saving of one year for reinvestment in his practice, subject to appropriate safeguards.

For 23 years the cost of prescribing in this practice has not been above $75 \%$ of the area average-in which time the practice population has increased $3 \frac{1}{2}$ times and has changed from mainly British working class to having a substantial minority of new Commonwealth immigrants. For example, last June the average cost per person on our NHS prescribing list was $0.38 p$ compared with $0.55 p$ per head average for the area. Taking our list as 10500 patients and projecting this (a quiet month of the year) over a period of 12 months our practice has saved at least $£ 21420$ compared with the average cost of prescribing for a similar number of patients. Some part of these savings should 